\title{
Potensi Sinergitas Fintech Dengan Bank Syariah Dalam Meningkatkan Kinerja Perbankan Syariah Di Indonesia
}

\author{
Rola Nurul Fajrial \\ ${ }^{1}$ Politeknik Negeri Semarang, Semarang \\ $\bowtie$ rola.nurulfajria@gmail.com
}

\begin{abstract}
: Technology start-ups from FinTech firms offer more convenient user experiences for example better user interfaces for the mobile management of personal finance. Beside that also lower prices and better quality for example faster speed for traditional products such as payment services. This study aims to identify and overview about key riks and impact of FinTech on sharia banks in Indonesia to improving bank performance. The result of this study shows that shariah banking Indonesia needs for synergy with FinTech firm to increase their performanceand market share.
\end{abstract}

Keywords $\quad$ : FinTech, Sharia Banking, Market Share

\section{LATAR BELAKANG}

Dewasa ini dengan kemajuan teknologi, dunia perbankan mulai berevolusi dalam melakukan layanan maupun produknya. Melalui akses internet, nasabah mampu melakukan transaksi keuangan maupun non keuangan dimana saja dan kapan saja. Namun sejak krisis tahun 2008, bank mengalami kesulitan dengan tingkat suku bunga yang rendah, pendapatan menurun, ketidakpercayaan pelanggan, kurangnya loyalitas, dan meningkatnya biaya (Capgemini, 2018).

Peraturan untuk bank telah diperketat sejak krisis untuk meningkatkan stabilitas keuangan dan perlindungan konsumen. Pengetatan ini dapat berupa biaya tambahan untuk bank (yang dibayar oleh nasabah) karena adanya persyaratan dokumentasi yang lebih ketat dan lebih banyak kontrol internal terhadap kesalahan penjualan produk. Peraturan perlindungan konsumen yang baru telah diperlukan dalam restrukturisasi prosedur frontoffice, termasuk dalam identifikasi kebutuhan pelanggan yang tepat, penilaian kemampuan finansial mereka, pemilihan produk yang paling cocok, dan restrukturisasi insentif untuk penjualan oleh staf bank.Dengan meningkatnya biaya yang harus dikeluarkan oleh nasabah, maka dengan hadirnya FinTech dapat mengatasi hal tersebut. Teknologi start-up oleh perusahaan FinTech menawarkan pengalaman yang lebih nyaman bagi pengguna, misalnya penampilan antarmuka pada seluler untuk pengelolaan manajemen keuangan pribadi yang lebih mudah. Selain itu, harga yang lebih rendah dan kualitas yang lebih baik, misalnya kecepatan lebih tinggi jika dibandingkan pelayanan oleh produk bank pada layanan pembayaran (IFSB, 2017)..

Perusahaan FinTech mampu memberikan penawaran teknologi yang cepat dengan biaya yang rendah. Namun kesulitan dalam mendapatkan konsumen karena 
tidak memiliki basis data terkait konsumen yang potensial. Hal tersebut berbanding terbalik dengan industri perbankan, dimana mereka memiliki basis data yang besar namun lemah dalam penggunaan inovasi teknologi. Untuk itu perlu sinergitas antara industri perbankan dan perusahaan FinTech.

Melalui kemajuan teknologi, maka bank syariah perlu menawarkan layanan pelanggan melalui saluran digital. Namun hingga sekarang, bank syariah belum optimal memanfaatkan momen tersebut. Meskipun layanan dasar seperti permintaan dan transfer akun ditawarkan secara online, interaktif dan layanan lanjutan belum ditawarkan melalui internet dan mobile banking. Hal tersebut perlu dilakukan oleh bank syariah agar tidak tertinggal dengan bank konvensional yang mulai melakukan kerjasama dengan perusahaan FinTech dalam pelayanannya. Mengadopsi inovasi dari FinTech bukan merupakan sebuah opsi namun sebagai imperatif absolut bagi bank partisipasi untuk melanjutkan dalam meningkatkan pangsa pasar. (Banking in emerging markets, GCC FinTech play 2017, EY).

\section{TEORI DAN METODE}

\subsection{Definisi fintech}

Menurut Financial Stability Board (FSB), definisi kerja untuk FinTech adalah "inovasi keuangan yang dimungkinkan secara teknologi yang dapat menghasilkan model bisnis baru, aplikasi, proses, atau produk dengan efek material yang terkait pada pasar keuangan, institusi dan penyediaan layanan keuangan". Sementara secara luas istilah "FinTech" dapat digunakan untuk menggambarkan berbagai inovasi, kekhususan lebih lanjut diperlukan untuk inovasi individu.

Sedangkan menurut International Organization of Securities Commissions (IOSCO), istilah Teknologi Keuangan atau "FinTech" digunakan untuk menggambarkan berbagai model bisnis inovatif dan teknologi baru yang berpotensi mengubah industri jasa keuangan:

a. Model bisnis FinTech yang inovatif biasanya menawarkan satu atau lebih spesifik produk atau layanan keuangan dalam mode otomatis melalui penggunaan internet. Dengan melakukan tersebut, mereka memisahkan layanan keuangan yang berbeda yang secara tradisional ditawarkan oleh penyedia layanan - bank petahana, broker atau manajer investasi. Misalnya, platform ekuitas crowdfunding untuk penempatan saham menengah; platform pinjaman peer-to-peer untuk pinjaman intermediasi atau menjual pinjaman; robo-adviser memberikan saran investasi secara otomatis; dan platform perdagangan sosial menawarkan layanan broker dan investasi.

b. Munculnya teknologi seperti komputasi kognitif, pembelajaran mesin, buatan kecerdasan, dan distributed ledger technologies (DLT) dapat digunakan untuk melengkapi keduanya baik FinTech sebagai pendatang baru dan petahana tradisional, dan membawa potensi untuk secara material mengubah industri jasa keuangan. 


\subsection{Metode Penelitian}

Metode yang digunakan dalam penelitian ini adalah motede kualitatif dengan pendekatan library research. Penelitian ini berusaha melacak potensi fintech dan bank syariah. Untuk melacak data, peneliti melakukan tahapan dokumentasi dan melakukan beberapa review jurnal yang sesuai dengan tema penelitian.

\section{HASIL DAN PEMBAHASAN}

\subsection{FinTech dalam lintasan sejarah}

FinTech bukanlah hal yang baru, dimana sudah diterapkan sejak tahun 1990 an dan sekarang mulai berkembang dan memasuki pasar layanan jasa keuangan. Evolusi FinTech telah berkembang dalam tiga tahap, yaitu FinTech 1.0, terjadi dari tahun 1866 hingga tahun 1967, FinTech 2.0, dari tahun 1968 hingga tahun 2008, dan FinTech 3.0 dari tahun 2009 hingga sekarang. FinTech 1.0 muncul ketika layanan keuangan ketika layanan keuangan industri tetap masih sebagian besar analog meskipun sudah terkait dengan teknologi. Periode berikutnya, FinTech 2.0, merupakan sebuah era yang dicirikan oleh perkembangan teknologi digital untuk komunikasi dan transaksi dan dengan demikian digitalisasi keuangan yang sedang tumbuh. Sejak 2009, pada periode FinTech 3.0, baru banyak berdirinya startup dan teknologi mapan, e-commerce, dan perusahaan media sosial telah mulai memberikan produk dan layanan keuangan secara langsung kepada publik dan juga bisnis, termasuk bank (Arner, 2017).

\section{FinTech 1.0 (1866-1967)}

Perkembangan keuangan dan teknologi memiliki sejarah yang panjang. Pada akhir abad ke 19, teknologi seperti telegraf, rel kereta api, dan kapal uap membantu menjalin hubungan keuangan lintas batas. Pada tahun 1866, infrastruktur fundamental mampu memperkuat keuangan globalisasi (perkembangan dari tahun 1866 hingga tahun1913) yaitu peletakan dari kabel transatlantic telegrap, diikuti dengan kiriman cepat pada perkembangan teknologi Perang Dunia II. Pada akhir periode ini, sebuah jaringan teleks global telah dilaksanakan, yang menyediakan landasan komunikasi yang menjadi tahap selanjutnya dari FinTech (Arner, 2017).

\section{FinTech 2.0 (1967-2008)}

Kemajuan pesat dalam sistem pembayaran elektronik terjadi pada akhir 1960-an dan 1970an. Pelayanan kliring otomatis modern dibentuk oleh pembentukan Inter-Bank Computer Bureau di Inggris pada tahun 1968. Kemudian diikuti oleh Sistem Pembayaran Antar Bank Kliring di Amerika Serikat pada tahun 1970. Oleh karena itu, kebutuhan untuk menghubungkan sistem pembayaran domestic diperlukan, sehingga Society of Worldwide Interbank Financial Telecommunications (SWIFT) didirikan pada tahun 1973. Namun pada tahun 1974 Herstatt Bank mengalami kebangkrutan yang menjadikan sebuah peristiwa yang menyoroti akan risiko meningkatnya hubungan keuangan internasional. Krisis ini berfungsi sebagai katalis untuk prakarsa pembentukan Komite Kebijakan Perbankan dan Praktek Pengawasan oleh kelompok sepuluh negara Gubernur bank sentral pada akhir tahun 1974 sebagai akibat dari 
gangguan serius dalam mata uang internasional dan pasar perbankan (terutama kegagalan Bankhaus Herstatt di Jerman Barat) (BCBS, 2018).

\section{FinTech 3.0 (2009-sekarang)}

Survei pada tahun 2015 melaporkan bahwa orang Amerika mempercayai perusahaan teknologi jauh lebih banyak daripada bank untuk menangani keuangan mereka. Begitu juga dengan yang terjadi di China, dimana lebih dari 2.000 platform peer-to- peer (P2P) memberikan penawaran pinjaman yang di luar kerangka peraturan yang telah ditetapkan yaitu biaya lebih rendah, potensi keuntungan yang kembali lebih tinggi dan meningkat pelayanan kenyamanan (Alois, 2015). Faktor pembeda utama dari FinTech 3.0 adalah tingkat perkembangan teknologi yang cepat dan perubahan identitas dari penyedia layanan keuangan jasa. Dibandingkan FinTech 2.0 yang lebih fokus pada digitalisasi bank, pada periode FinTech 3.0 lebih mencakup pada banyaknya peran perusahaan startup dan perusahaan teknologi dalam bisnis perdagangan elektronik secara digital. Perusahaan startup dan perusahaan teknologi tersebut telah menantang lembaga-lembaga keuangan yang sudah mapan dengan menawarkan layanan khusus, ceruk kepada konsumen, bisnis, dan lembaga keuangan petahana (Arner, 2017).

\subsection{Implikasi FinTech Bagi Bank Dan Sistem Perbankan}

Basel Committee on Banking Supervision (BCBS) menerbitkan Sound Practices on the Implications of FinTech Developments for Banks and Bank Supervisors, yang menilai bagaimana inovasi yang didorong teknologi dalam layanan keuangan, atau FinTech, dapat mempengaruhi industri perbankan dan kegiatan pengawas dalam jangka menengah. Hal ini didasarkan pada analisis berbagai skenario potensial masa depan dan mengacu pada survei kerangka kerja dan praktik pengawas perbankan dalam kaitannya dengan masalah-masalah FinTech. Sejumlah skenario diidentifikasi yang menggambarkan dampak potensial FinTech pada bank dengan risiko dan peluang khusus mereka. Berikut bagian dari analisis skenario di seluruh industri.

Tabel 2.1. Deskripsi Risiko Utama Tiap Skenario Bank

\begin{tabular}{|l|l|}
\hline Skenario Bank & Analisis Risiko \\
\hline Bank Terbaik & $\begin{array}{l}\text { Risiko utama dalam skenario bank yang terbaik fokus pada risiko } \\
\text { pelaksanaan terkait dengan penerapan strategi baru (kemampuan bank } \\
\text { untuk mengelola dan menerapkan secara efektif perubahan teknologi dan } \\
\text { proses bisnis) dan risiko strategis dan profitabilitas. Bahkan dalam } \\
\text { skenario bank terbaik, ada kemungkinan persaingan yang ketat di antara } \\
\text { para pemain incumbent untuk memilih strategi kemenangan dan waktu } \\
\text { yang tepat untuk memasarkan. Sementara beberapa aspek manajemen } \\
\text { risiko operasional dapat mengambil manfaat dari proses perbankan yang } \\
\text { lebih baik dan lebih efisien, risiko operasional dapat meningkat karena } \\
\text { perkembangan lebih } \\
\text { lanjut risiko cyber dan peningkatan ketergantungan pada outsourcing. }\end{array}$ \\
\hline Bank Baru & $\begin{array}{l}\text { Ukuran dan skala dari banyak bank petahana mungkin membuat sulit } \\
\text { untuk memodernisasi dan mendigitalkan proses mereka saat ini secara } \\
\text { efektif untuk mencapai operasi yang efektif serta untuk menyediakan } \\
\text { produk-produk inovatif untuk pelanggan dalam jangka waktu yang dapat } \\
\text { diterima. }\end{array}$ \\
\hline
\end{tabular}




\begin{tabular}{|c|c|}
\hline Bank Terdistribusi & $\begin{array}{l}\text { Risiko utama yang disoroti adalah kemampuan bank dan pengawas bank } \\
\text { untuk memantau dan mengelola transaksi end-to-end di satu atau } \\
\text { beberapa pihak ketiga. Juga, pertanyaan tentang kepemilikan hubungan } \\
\text { pelanggan dan penggunaan data pelanggan berkaitan dengan } \\
\text { perlindungan konsumen dan peraturan perlindungan data yang } \\
\text { merupakan bagian dari skenario bank terdistribusi. Akhirnya, mungkin } \\
\text { ada pertanyaan tentang fungsi manajemen risiko sebagai konsekuensi } \\
\text { dari hubungan pelanggan yang lebih lemah, kurang stabil, dan lebih } \\
\text { terfragmentasi. Hilangnya hubungan pelanggan dapat mengakibatkan } \\
\text { hilangnya pendapatan dan peluang penjualan silang. Selain itu, di sisi } \\
\text { kepatuhan, bank harus memiliki proses pemantauan AML / CFT yang } \\
\text { sesuai jika mereka memproses } \\
\text { transaksi atas nama pelanggan perusahaan FinTech. }\end{array}$ \\
\hline Bank Terdegadrasi & $\begin{array}{l}\text { Skenario ini, bank menjadi penyedia layanan back office untuk platform } \\
\text { pelayanan front office, dengan bank yang menyediakan lisensi yang } \\
\text { diperlukan, akses ke jaringan pembayaran dan mempertahankan } \\
\text { simpanan dan akses ke pendanaan. Ada risiko bahwa bank dan pengawas } \\
\text { bank akan memiliki kemampuan terbatas untuk memantau transaksi end- } \\
\text { to-end dan risiko sistemik. Seperti dalam skenario bank terdistribusi, } \\
\text { hilangnya hubungan pelanggan dan ketergantungan pada platform baru } \\
\text { ini yang menyalurkan produk keuangan dapat menimbulkan konsekuensi } \\
\text { yang merugikan bagi fungsi manajemen risiko dan aliran pendapatan } \\
\text { (pendapatan harus dibagi dengan perantara baru). Skenario ini juga } \\
\text { menimbulkan masalah yang signifikan untuk perlindungan konsumen, } \\
\text { karena hubungan pelanggan akan ditangani oleh platform baru, yang } \\
\text { akan didasarkan pada proses otomatis dan penggunaan data konsumen } \\
\text { yang ekstensif dan inovatif. Selain privasi data dan masalah keamanan } \\
\text { data, praktik pemasaran yang tidak pantas dapat muncul dalam skenario } \\
\text { ini. Jika jumlah platform baru rendah, risiko } \\
\text { konsentrasi akan meningkat, terutama jika perusahaan bigtech } \\
\text { mendapatkan pangsa pasar yang besar. }\end{array}$ \\
\hline $\begin{array}{l}\text { Bank } \\
\text { Disintermediasi }\end{array}$ & $\begin{array}{l}\text { Skenario bank disintermediasi dianggap tidak mungkin untuk } \\
\text { mendapatkan skala yang signifikan dalam jangka pendek dan menengah. } \\
\text { Memang, penggunaan buku besar umum didistribusikan secara besar- } \\
\text { besaran untuk pembayaran pemrosesan masih terhambat oleh banyak } \\
\text { faktor teknologi dan hukum. Platform pinjaman P2P juga menghadapi } \\
\text { kesulitan dalam pencocokan pinjaman dan pinjaman, yang } \\
\text { menggarisbawahi kebutuhan ekonomi berkelanjutan untuk intermediasi } \\
\text { neraca. Selain itu, platform pinjaman P2P saat ini berputar ke model } \\
\text { bisnis di mana investor institusi seperti bank, dana pensiun atau } \\
\text { perusahaan asuransi semakin menggantikan investor ritel di basis } \\
\text { investor. Hal ini karena ada risiko potensial bahwa bank dapat } \\
\text { disintermediasi dari aspek- aspek tertentu dari layanan keuangan. Risiko } \\
\text { utama dalam skenario ini adalah bahwa aktivitas keuangan yang terjadi } \\
\text { di luar lingkungan peraturan akan tunduk pada standar dan pengawasan } \\
\text { yang lebih longgar, dan sebagai akibatnya secara inheren kurang } \\
\text { terkontrol dan } \\
\text { aman. Pengawas bank berpotensi menemukan bahwa kemampuan }\end{array}$ \\
\hline
\end{tabular}


mereka untuk memantau area risiko sistemik dalam industri keuangan terkikis (BCBS, 2018).

\subsection{Kinerja Perbankan Syariah Di Indonesia}

Meskipun Indonesia merupakan negara dengan populasi Muslim terbesar, namun penetrasi perbankan syariah di Indonesia masih rendah. Hal ini dibuktikan dengan pangsa pasar perbankan syariah di Indonesia hanya mencapai 5, 78\% pada tahun 2017. Industri perbankan syariah di Indonesia didominasi 66,21\% dari Bank Umum Syariah (BUS), 31,30\% dari Unit Usaha Syariah (UUS) dan 2,49\% dari Bank Pembiayaan Syariah (BPRS). Dari sisi pangsa pasar memang masih rendah dibandingkan perbankan konvensional, akan tetapi perbankan syariah di Indonesia menunjukkan perkembangan positif. Hal ini ditunjukkan dengan tingginya pertumbuhan Aset, Pembiayaan yang Disalurkan (PYD), dan Dana Pihak Ketiga (DPK).

Tabel 2.2 Indikator Utama Perbankan Syariah Tahun 2012-2017

\begin{tabular}{|l|l|l|l|l|l|l|}
\hline Indikator & 2012 & 2013 & 2014 & 2015 & 2016 & 2017 \\
\hline Aset & 199,71 & 248,11 & 278,90 & 304,00 & 365,6 & 435,02 \\
\hline DPK & 150,44 & 187,19 & 221,89 & 236,02 & 285,2 & 341,07 \\
\hline PYD & 151,06 & 188,55 & 204,31 & 218,72 & 254,7 & 291,18 \\
\hline $\begin{array}{l}\text { Market } \\
\text { Share }\end{array}$ & $4,58 \%$ & $4,89 \%$ & $4,85 \%$ & $4,88 \%$ & $5,55 \%$ & $5,78 \%$ \\
\hline & & & & & & \\
\hline BOPO & $74,97 \%$ & $78,21 \%$ & $94,16 \%$ & $94,38 \%$ & $93,63 \%$ & $89,62 \%$ \\
\hline NPF Nett & $1,34 \%$ & $1,75 \%$ & $2,94 \%$ & $2,77 \%$ & $2,06 \%$ & $2,13 \%$ \\
\hline NPF Gross & $2,22 \%$ & $2,62 \%$ & $4,33 \%$ & $4,34 \%$ & $4,15 \%$ & $3,87 \%$ \\
\hline CAR & $14,13 \%$ & $14,44 \%$ & $16,10 \%$ & $15,02 \%$ & $16,16 \%$ & $17,91 \%$ \\
\hline FDR & $100,00 \%$ & $100,32 \%$ & $91,50 \%$ & $92,14 \%$ & $88,87 \%$ & $85,31 \%$ \\
\hline \multicolumn{7}{|c|}{ Sumber: Statistik Perbankan Syariah 2017} \\
\end{tabular}

Berdasarkan Tabel 2.2, NPF menurun pada tahun 2017 menjadi 3,87\%, dimana sebelumnya pada tahun 2016 sebesar 4,15\%. Penurunan tersebut tidak menggambarkan penurunan risiko pembiayaan tetapi disebabkan adanya restrukturisasi pembiayaan dalam jumlah yang signifikan. Selain itu juga pertumbuhan pembiayaan yang rendah bahkan menurun. Hal tersebut disajikan pada rasio FDR, dimana sejak tahun 2013 hingga tahun 2017 jumlah pembiayaan yang disalurkan mengalami penurunan dari $100,32 \%$ menjadi $85,31 \%$.

\subsection{Potensi Sinergitas FinTech dengan Bank Syariah}

Dari sisi Aset, Pembiayaan yang Disalurkan (PYD), dan Dana Pihak Ketiga (DPK), perbankan syariah memang mengalami pertumbuhan yang positif. Namun, jika dilihat dari sisi penyaluran pembiayaan dan kualitas pembiayaan cukup berisiko. Penurunan rasio NPF tidak mengindikasikan menurunnya risiko pembiayaan yang disalurkan perbankan syariah. Untuk itu, perlu adanya alternatif pembiayaan dengan risiko rendah dan aman. Salah satunya dengan melakukan sinergitas antara perbankan syariah dan perusahaan FinTech. 
Inovasi yang ditawarkan oleh perusahaan FinTech dapat memberi dampak positif pada konsumen maupun perbankan. Bagi konsumen, dengan adanya FinTech, biaya transaksi yang dikeluarkan lebih rendah dan pelayanannya lebih cepat dibandingkan bank. Sedangkan bagi perbankan, dengan adanya FinTech, maka terdapat peningkatan dan efisiensi dalam proses pelayanan perbankan.

Basel Committee on Banking Supervision (BCBS) menyimpulkan bahwa pengadopsian teknologi memungkinkan munculnya model bisnis baru yang dapat menimbulkan berbagai peluang dan risiko bagi bank petahana. Secara lebih lanjut mencatat bahwa standar perbankan dan harapan pengawasan harus adaptif terhadap inovasi baru sambil mempertahankan standar kehati-hatian yang sesuai. BCBS mengidentifikasi 10 implikasi utama dan pertimbangan terkait untuk bank dan pengawas bank:

a. kebutuhan menyeluruh untuk memastikan keselamatan dan kesehatan serta standar kepatuhan yang tinggi tanpa menghambat inovasi yang menguntungkan di sektor perbankan;

b. risiko utama bagi bank terkait dengan perkembangan FinTech, termasuk risiko strategis / profitabilitas, operasional, risiko siber dan risiko kepatuhan;

c. implikasi bagi bank-bank atas penggunaan teknologi pendukung yang inovatif;

d. implikasi bagi bank-bank dari meningkatnya penggunaan pihak ketiga, melalui alih daya dan / atau kemitraan;

e. kerjasama lintas sektoral antara pengawas bank dan otoritas terkait lainnya;

f. kerjasama internasional antara pengawas bank;

g. adaptasi dari set keterampilan pengawasan;

h. peluang potensial bagi pengawas untuk menggunakan teknologi inovatif

i. relevansi kerangka peraturan yang ada untuk model bisnis baru yang inovatif; dan

j. fitur utama dari inisiatif pengaturan yang disiapkan untuk memfasilitasi inovasi FinTech

\section{PENUTUP}

Hasil penelitian ini menunjukkan bahwa Sinergitas FinTech dengan Bank Syariah dapat menjadi alternatif pembiayaan untuk meningkatkan produktivitas kinerja perbankan syariah. Saran untuk peneliti selanjutnya agar mengganti metode analisis atau mengganti variabel lain yang sekiranya berpotensi memiliki pengaruh terhadap perkembangan FinTech syariah dan perbankan syariah. 


\section{DAFTAR PUSTAKA}

Alois, J. 2016, "Ethiskapital claims 'world's first' licensed Islamic P2P/crowdfunding platform", Crowdfund Insider, 3 November. Diakses dari www.crowdfundinsider.com/2016/11/92018-ethiskapital-claims-worlds-first licensed-islamicp2pcrowdfunding-platform/.

Arner, Douglas W, Janos Barberis dan Ross P. Buckley. 2016. The Evolution of Fintech: A New Post - Crisis Pradigm?. University of Hong Kong Faculty of Law, Research Paper No. 2015/047.

Basel Committee on Banking Supervision 2003. Sound Practices for the Management and Supervision of Operational Risk.

Basel Committee on Banking Supervision. 2018 . Sound Practices for Implications of fintech developments for banks and bank supervisors

Capgemini. 2018. World Fintech Report 2018.

MIFC. 2016. Islamic Finance Technology \& Innovation.

IOSCO. 2017. Research Report on Financial Technologies (FinTech)

OJK. 2017. Roadmap Pengembangan Keuangan Syariah Indonesia 2017-2019.

OJK. 2017. Statistik Perbankan Syariah 2017. 